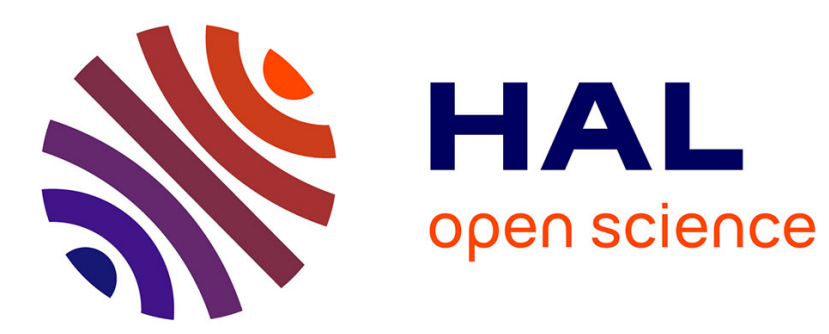

\title{
Patterns of otter road mortality in a landscape abundant in lakes
}

Saskia Jancke, Peter Giere

\section{To cite this version:}

Saskia Jancke, Peter Giere. Patterns of otter road mortality in a landscape abundant in lakes. European Journal of Wildlife Research, 2010, 57 (2), pp.373-381. 10.1007/s10344-010-0442-5 . hal00631263

\section{HAL Id: hal-00631263 https://hal.science/hal-00631263}

Submitted on 12 Oct 2011

HAL is a multi-disciplinary open access archive for the deposit and dissemination of scientific research documents, whether they are published or not. The documents may come from teaching and research institutions in France or abroad, or from public or private research centers.
L'archive ouverte pluridisciplinaire HAL, est destinée au dépôt et à la diffusion de documents scientifiques de niveau recherche, publiés ou non, émanant des établissements d'enseignement et de recherche français ou étrangers, des laboratoires publics ou privés. 


\title{
Patterns of otter Lutra lutra road mortality in a landscape abundant in lakes
}

\author{
Saskia Jancke • Peter Giere
}

Received: 30 September 2009 /Revised: 30 August 2010 / Accepted: 1 September 2010 /Published online: 12 October 2010

(C) Springer-Verlag 2010

\begin{abstract}
In order to reduce otter (Lutra lutra) road mortality and to predict accident sites, we assessed the localities of traffic accidents involving otters in the Uckermark County, Brandenburg, Northeast Germany. Eighty-eight otter accident sites from the years 1990 to 2003 - as recorded by the Naturschutzstation Zippelsförde des Landesumweltamtes Brandenburg (Brandenburg State Office for Environment) - were categorised according to traffic and road patterns, otter habitat suitability, as well as presence and type of watercourse crossings. From these numerical data, we compiled a list of characteristics to identify other potentially dangerous sites where otter road traffic accidents are likely to occur using a geographic information system. With a principal component analysis, we categorised three groups of accident sites. Firstly, most otter road accidents were located close to either one or two lakes. Secondly, otters were frequently killed at places where no body of water occurred within a distance of $200 \mathrm{~m}$ to the road. Thirdly, and in contrast to other locations, in the Uckermark County, fewest accidents happened where a road crossed a watercourse. Mitigation measures were suggested and discussed for the recorded and potential accident sites.
\end{abstract}

Keywords Road kill $\cdot$ Habitat connectivity $\cdot$ Mitigation measures $\cdot$ Uckermark County $\cdot$ Germany

Communicated by H. Kierdorf

S. Jancke $(\bowtie) \cdot$ P. Giere

Museum für Naturkunde, Leibniz Institute for Research on

Evolution and Biodiversity, at the Humboldt University Berlin, Invalidenstraße 43,

10115 Berlin, Germany

e-mail: saskia.jancke@googlemail.com

P. Giere

e-mail: peter.giere@mfn-berlin.de

\section{Introduction}

Eurasian otters Lutra lutra suffered a widespread decline in Central Europe over the last century due to persecution, habitat loss and pollution of watercourses with pesticides (Grogan et al. 2001; Macdonald 1995; Strachan and Jeffries 1996).

The otter is listed in Appendix II of the Council of Europe Convention on the Conservation of European Wildlife and Natural Habitats (Council of Europe 1996) and in Appendix I of CITES (International Union for Conservation of Nature 2009). Otters are further protected under European law, being listed in Annex IIa and IVa of EC Directive 92/43, Conservation of Natural Habitats and Wild Fauna and Flora (the "Habitats Directive"). In the Red List of Germany, Eurasian otters are listed as an endangered species (Binot et al. 1998).

Road mortality replaced drowning and trapping (Stubbe 1977, 1978) as the predominant cause of otter deaths recorded in Europe (Green and Green 1997; Hauer et al. 2002; Körbel 2001; Sommer et al. 2005; Stubbe et al. 1993; Wölfel and Tessendorf 2000; Zinke 1998), and the numbers of otters killed on roads are increasing (Green 1991; Grogan et al. 2001; Zinke 1991, 1998). Despite the likelihood of being better recorded than other forms of mortality, road mortality is expected to have a strong impact on populations (Philcox et al. 1999). Furthermore, traffic collisions with otters may pose a risk to motorists. Consequently, a methodology for predicting potential accident sites involving wildlife is increasingly important.

In many other regions, otter road accidents mainly occur where roads cross watercourses (Grogan et al. 2001; Körbel 2001; Philcox et al. 1999) because otters avoid swimming underneath bridges but instead often leave the watercourse to cross the road. So far, different explanations for this 
behaviour have been brought forward (Grogan et al. 2001; Körbel 2001; Madsen 1996). In the Uckermark County, however, the abundance of lakes creates a potentially different situation regarding accident sites.

Strongholds of otters are nowadays found in Ireland and Britain. Some parts of Central Europe (e.g., Germany and Austria) appear to support fragmented populations, while otters are extinct in Switzerland (Kranz et al. 2008) and the Netherlands, where reintroduction attempts took place (de Jongh 1999; Grogan et al. 2001; Weber et al. 1991).

The state of Brandenburg is one of the few regions in Germany with stable populations of otters (Teubner et al. 1999). Their existence in Germany is mainly threatened by habitat fragmentation and an increasing volume of road traffic (Ansorge 1994; Dolch et al. 1998; Uthleb et al. 1992; Wölfel and Tessendorf 2000; Zinke 1998).

The aims of our research were to find characteristics of typical otter road accident sites in the lake-dominated landscape of the Uckermark County, predict potential accident sites using geographic information system (GIS) tools and, ultimately, to find adequate mitigation measures to reduce otter road mortality.

\section{Materials and methods}

Study area

The study area comprises the entire Uckermark County, which is located in the northeast of the state of Brandenburg in Northeast Germany. Covering an area of 3,058 $\mathrm{km}^{2}$, it is the largest county of Germany with a relatively low population density of 47 residents per square kilometre. The Uckermark County has 600 lakes larger than 1 ha and $2,800 \mathrm{~km}$ of watercourses (Fig. 1). The landscape comprises dry grassland, heathland and forest. About $60 \%$ of the area is intensively used for agriculture, while around $50 \%$ is designated for nature conservation.

Due to the abundance of water bodies and the relatively low human population density, the Uckermark County offers good conditions for the otters, which are distributed all over the area (Teubner et al. 1999). Otter populations in the Uckermark County are connected with those in the state of Mecklenburg-Western Pomerania and in Poland by watercourses such as the rivers Oder and Untere Havel (Dolch et al. 1992).

Data collection and causes of mortality

All otters found dead in the Uckermark have routinely been recorded by the Naturschutzstation Zippelsförde des Landesumweltamtes Brandenburg (Brandenburg State Office for
Environment) since 1990. The records provide information about the cause of death, date and location of the finding (marked on a 1:25,000 map) and, in some cases, details about the finder as well as about the specimen found (size, weight, sex, age and nutritional condition).

For the present study, accident sites from the years 1990 2003 (Fig. 1) were characterised with features of traffic and road patterns, otter habitat suitability, as well as watercourse crossings modified from Ebersbach and Hauer (1998, unpublished report: Untersuchungen zur Lebensraumgestaltung und Biotopvernetzung für den Fischotter-Erkennen von Gefahren, Aufzeigen von Lösungen und Maßnahmen. Abschlußbericht zum Fischotterprojekt im Spree-NeißeKreis im Auftrag des NABU-Landesverbandes Brandenburg e.V). Road patterns were examined to assess the influence of speed limit on the risk potential. Habitat features such as the surrounding vegetation, landscape, distance to the next watercourse, situation within a network of watercourses, size and characteristics of the water body were included in the survey to find out whether otters prefer certain habitat features or passage ways. All variables are listed and described in Table 1. River crossings are an important feature concerning the investigation of otter road mortality. Therefore, the presence and type of river crossings, as well as the presence and size of ledges or banks, were recorded to describe otter road accident sites.

\section{Statistical analysis}

For the distance between road and watercourse, as well as the number of casualties relating to speed limit, correlation coefficients of determination were calculated using parametric (for speed limit-Pearson's r) and nonparametric (distance between watercourse and road, Kendall's tau) tests of correlation.

Using SPSS 12.0, the main features of water bodies at the accident site, the occurrence and structure of a bridge, distance to the nearest body of water, vegetation at the accident site, flow velocity and the situation within a network of watercourses (all ordinal data) of the otter road accident sites were combined to two components using a principal component analysis (PCA). A preliminary analysis was accomplished to test the included variables for multicollinearity. An initial PCA was conducted to obtain the eigenvalues and to conclude the number of components.

Using these two components, the accident sites were plotted in a two-dimensional illustration. In this scatterplot, different groups of accident sites were identified. These groups were tested using a discriminant analysis in SPSS, which examines the significant difference of these groups. The features describing these groups were tested for significance $\left(\chi^{2}\right.$-test). 
Fig. 1 Study area Uckermark County (Brandenburg, Germany) and sites of otter road accidents $(n=88)$. Boxed area delineates region covered in Fig. 6

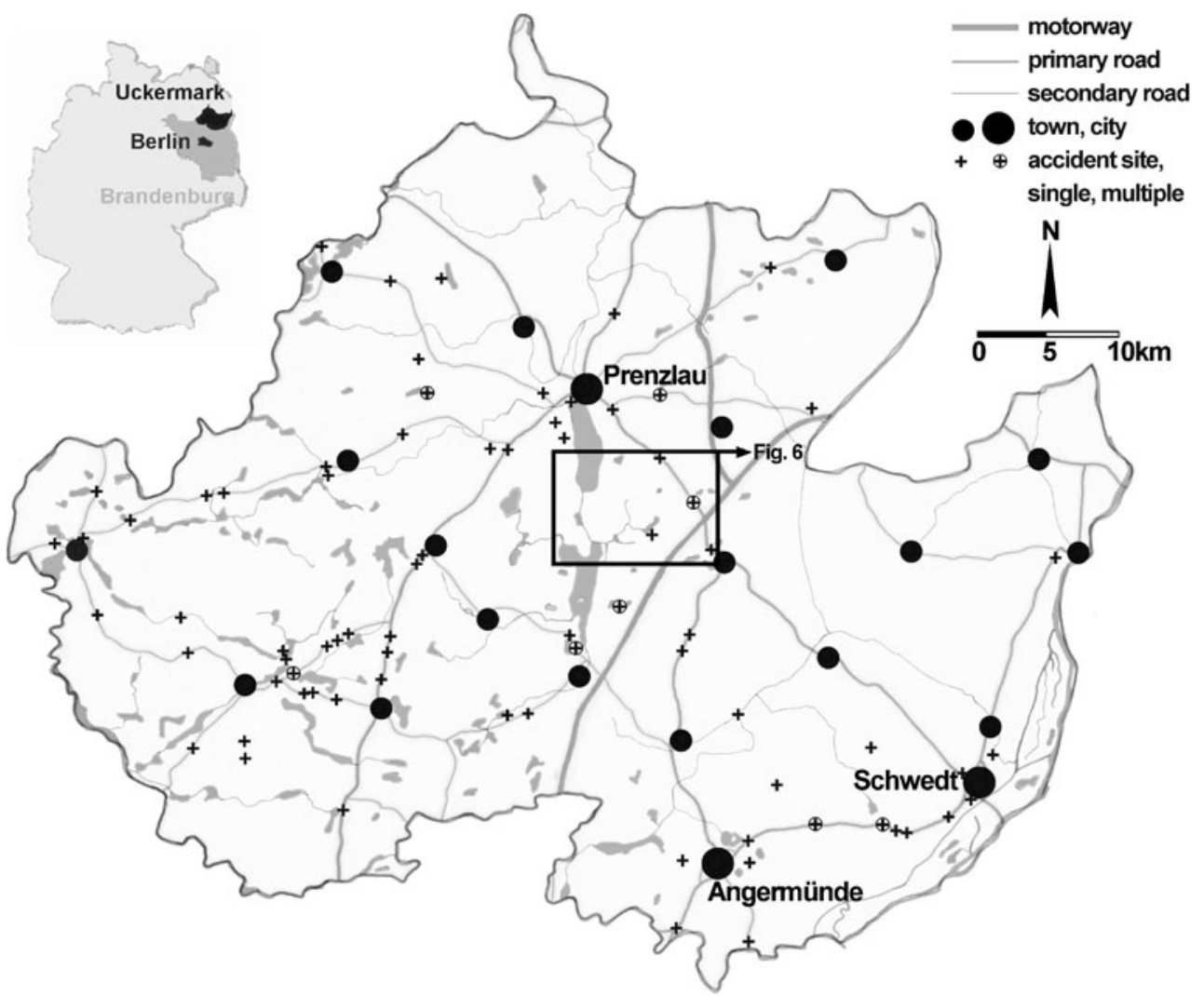

Geographic information system

ArcView GIS 3.2 was used to identify potential accident sites. ATKIS layers depicting the water distribution and road networks of the Uckermark as well as the topograph-

Table 1 Habitat variables assessed at otter accident sites in the Uckermark County, Germany (following Ebersbach and Hauer 1998, unpublished report: Untersuchungen zur Lebensraumgestaltung und Biotopvernetzung für den Fischotter-Erkennen von ical grid map of the area were provided by the Environment State Office of Brandenburg.

All roads on the road network layer were split into 100$\mathrm{m}$ fragments, while features within a significant distance to water bodies were selected by theme. The selected road

Gefahren, Aufzeigen von Lösungen und Maßnahmen. Abschlußbericht zum Fischotterprojekt im Spree-Neiße-Kreis im Auftrag des NABU-Landesverbandes Brandenburg e.V.)

Variable

Features

Width of watercourse $(\mathrm{m})$

Depth of watercourse (m)

Network of watercourses

Flow velocity

Bridge span (m)

Bridge clearance $(\mathrm{m})$

Width of ledge $(\mathrm{cm})$

Road at otter accident site

Distance to the nearest water body $(\mathrm{m})$

Width of road (m)

Roadside vegetation

Maximum speed $(\mathrm{km} / \mathrm{h})$
$<1,1-2,>2-5,>5-10,>10-20,>20$

$<0.5,0.5-1,1-2,2,>2$

Linear watercourse without major tributary, single branching watercourse on one side, small individual watercourses on either side, several branching watercourses on either side, network of ponds, network of lakes

Dry/stagnant water $(<0.1 \mathrm{~m} / \mathrm{s})$, slow $(0.1-1.5 \mathrm{~m} / \mathrm{s})$, fast $(>1.5 \mathrm{~m} / \mathrm{s})$, turbulent (with rapids)

$<0.5,0.5-0.8,>0.8-1,>1-1.2,>1.2-1.5,>1.5-1.8,>1.8-2,>2-3,>3-5,>5$

$<0.5,0.5-1,>1-1.5,>1.5-2,>2-2.5,>2.5-3,>3$

$<20,20-50,>50-100,>100-200,>200$

Crosses watercourse, parallel to watercourse, between ponds, parallel water bodies on either side, no water body present

$<50,50-100,>100-250,>250-500,>500-1000,>1000$

$<5,5-6,>6-7,>7-8,>8-10,>10-20,>20$

Forest, moor, bog, row of trees, forest edge, hedge, bushes, individual trees, individual bushes, none

$30,50,70,80,100,>100$ 
segments present potential accident sites, and locations thus identified were plotted on a topographical map.

\section{Results}

Spatial patterns and characteristics of otter road accident sites

Of the 88 otter road accident sites investigated, $68 \%$ were within $200 \mathrm{~m}$ of the nearest water body (Kendall's tau, $R^{2}=1.00, n=88, p<0.05$; Fig. 2). Sixteen percent of all accidents occurred at a distance of more than $500 \mathrm{~m}$ from a water body. The minority of otter road accidents were recorded where a linear watercourse (drainage ditch $11 \%$; streams, rivers and channels $11 \%$ ) intersected a road and therefore where a river crossing was present $(16 \%$ at culverts; $6 \%$ at bridges; Fig. 3). This finding is also represented by the low number of otter casualties found per kilometre around a bridge or culvert (which is defined as a 400-m stretch of road having a bridge or culvert in the centre). Only 4.8 otters per $100 \mathrm{~km}$ of bridge or culvert were found as opposed to 9.57 otter casualties per $100 \mathrm{~km}$ of roads in the Uckermark County (calculation based on unpublished data obtained from Brandenburg Road Administration). The number of casualties and the speed limit at the accident site were significantly positively correlated $\left(R^{2}=0.9623, n=88, p<.01\right.$; Fig. 4$)$.

A PCA was conducted on 12 variables with orthogonal rotation matrix (varimax). The Kaiser-Meyer-Olkin (KMO) measure verified the sampling adequacy for the analysis, $\mathrm{KMO}=0.628$ (Field 2009), and the Bartlett's test indicated that correlations between variables were large enough for PCA, $\chi^{2}=821.23, \mathrm{df}=66, p<0.001$ (Field 2009). An initial analysis was carried out in which the inflexion of the scree plot justified retaining either five components or two. Two components were obtained in the final analysis. Table 2

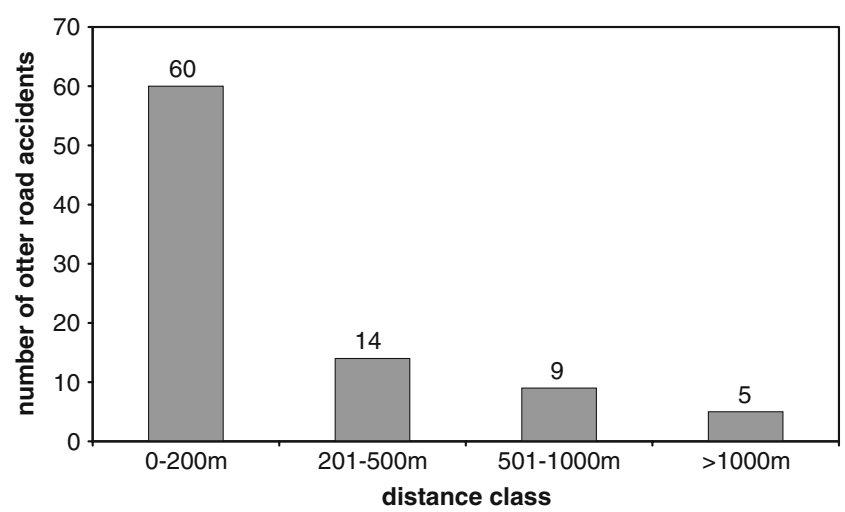

Fig. 2 Distance of accident sites to closest water body

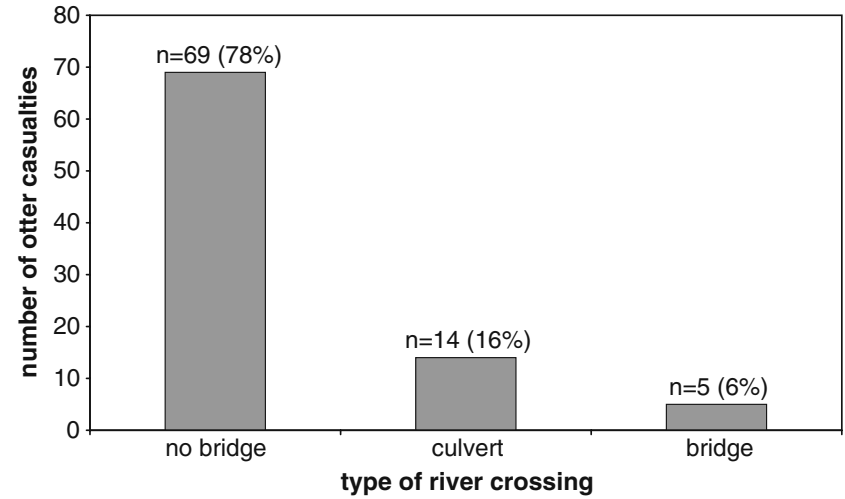

Fig. 3 River crossing at otter road accident sites $(n=88)$

shows the factor loadings after rotation. Component 1 refers to the presence of a water crossing, while component 2 represents the type of water body.

The two-dimensional illustration of all accident sites using the two components showed three groups of accident sites (Fig. 5). Grouping the sites and testing the groups with a discriminant analysis showed that $98 \%$ were correctly classified. The discriminant analysis revealed two discriminant functions. The first explained $91.5 \%$ of the variance, $R^{2}=0.987$. As apparent in Tables 3 and 4, both discriminant functions differentiate the groups significantly.

The investigation of the features describing these groups resulted in the following:

\section{Group 1}

The largest number of all accident sites $\left(n_{1}=39\right.$; $44.5 \%)$ were characterised by a lake located adjacent to a road $\left(\chi^{2}=14.308, \alpha<0.005, \mathrm{df}=2\right)$. There was no bridge at the accident site $\left(\chi^{2}=31.41, \alpha<0.001, \mathrm{df}=1\right)$, and the characteristic speed limit was at $100 \mathrm{~km} / \mathrm{h}\left(\chi^{2}=\right.$ 19.564, $\alpha<0.001, \mathrm{df}=3$ ).

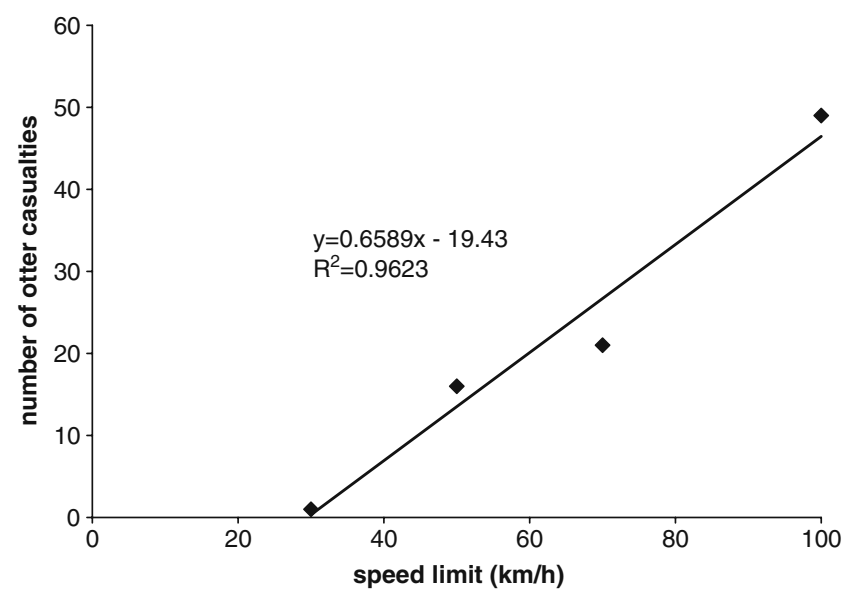

Fig. 4 Relation between the number of casualties and speed limit (kilometre per hour; $n=88$ ) 
Table 2 Summary of the PCA results for the characteristics of otter road accident sites in the Uckermark County

\begin{tabular}{lcc}
\hline Variables & \multicolumn{2}{l}{ Rotated factor loadings } \\
\cline { 2 - 3 } & Component 1 & Component 2 \\
\hline Width of waterbody & 0.097 & $\mathbf{0 . 9 6 4}$ \\
Depth of waterbody & 0.075 & $\mathbf{0 . 9 4 4}$ \\
Width of bridge & $\mathbf{0 . 9 2 7}$ & -0.178 \\
Height of bridge & $\mathbf{0 . 9 5 3}$ & -0.177 \\
Width of ledge & $\mathbf{0 . 7 8 0}$ & -0.188 \\
Distance to next watercourse & 0.015 & -0.262 \\
Width of road & -0.112 & -0.004 \\
Vegetation at accident site & 0.032 & -0.363 \\
Speed limit & -0.208 & -0.166 \\
Network of watercourses & 0.021 & -0.093 \\
Flow velocity of watercourse & $\mathbf{0 . 6 3 1}$ & $\mathbf{0 . 6 6 3}$ \\
Type of watercourse within $200 \mathrm{~m}$ & $\mathbf{0 . 8 1 5}$ & 0.373 \\
\hline
\end{tabular}

The extraction method used was PCA, and rotation method was varimax with Kaiser normalisation. Factor loadings over 0.40 are in boldface

\section{Group 2}

The second largest group $\left(n_{2}=31 ; 35 \%\right)$ consisted of accident sites where no body of water was present within 200 - $\mathrm{m}$ distance $\left(\chi^{2}=45.355, \alpha<0.001, \mathrm{df}=2\right)$. These accident sites were located in a network of water bodies

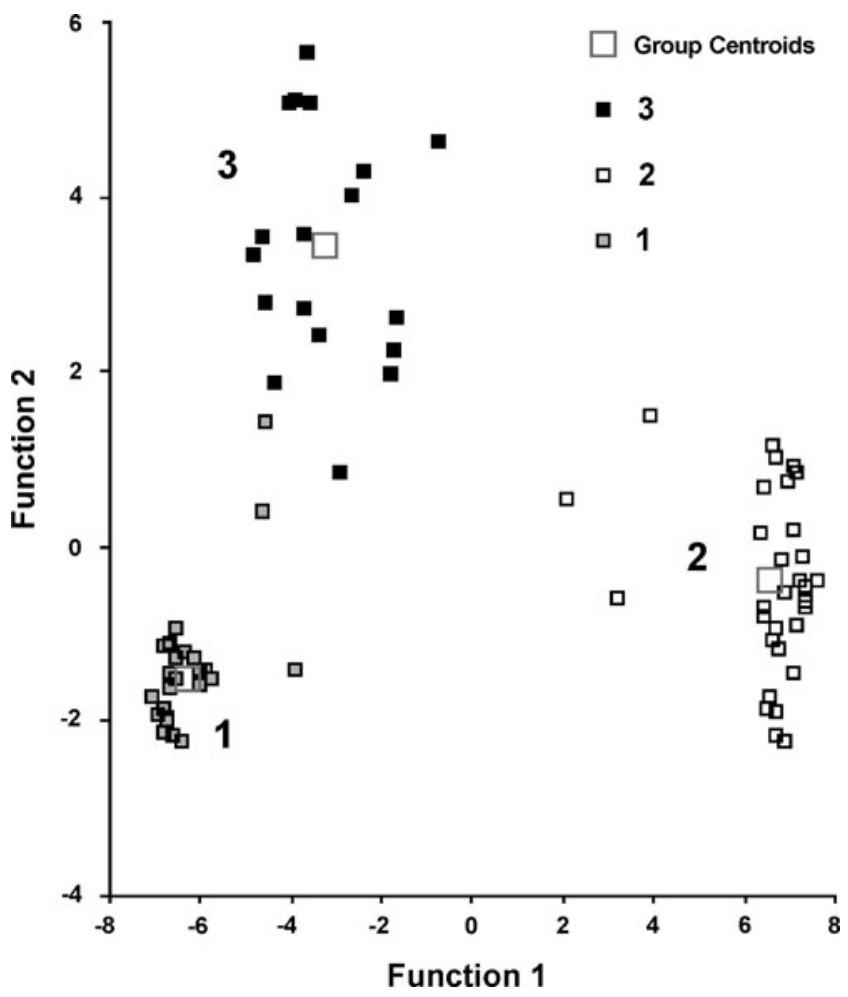

Fig. 5 Combined groups' plot of the canonical discriminant function in the surrounding area $\left(\chi^{2}=12.065, \alpha<0.05, \mathrm{df}=4\right)$, where the speed limit was $100 \mathrm{~km} / \mathrm{h}\left(\chi^{2}=31.839, \alpha<\right.$ $0.001, \mathrm{df}=3$ ).

Group 3

Fewest accident sites $\left(n_{3}=18 ; 20.5 \%\right)$ were located where a road crosses a watercourse $\left(\chi^{2}=8.000, \alpha=\right.$ $0.05, \mathrm{df}=1)$. Significant features describing the members of this group were a water depth of less than $0.5 \mathrm{~m}\left(\chi^{2}=\right.$ $10.889, \alpha<0.05, \mathrm{df}=1)$ and the presence of a culvert as watercourse crossing $\left(\chi^{2}=9.000, \alpha<0.05, \mathrm{df}=2\right)$. Speed limit was not a significant feature of this group $\left(\chi^{2}=\right.$ 1.333, $\alpha>0.05, \mathrm{df}=2$ ).

Prediction of potential accident sites using ArcView GIS

Using ArcView ${ }^{\circledR}$ GIS 3.2, 226 potential accident sites on roads within a distance of $200 \mathrm{~m}$ to one or more lakes were identified in the Uckermark County (cf. Fig. 6 for details). Thirty-three of these locations were identical with sites where 52 accidents involving otters had already been recorded. After assessing the respective speed limits in the field, 138 of the predicted accident sites were categorised as especially dangerous, as the speed limit was $100 \mathrm{~km} / \mathrm{h}$ or more. By extending the examined range to $500 \mathrm{~m}$ from the nearest body of water, 545 potential accident sites throughout the Uckermark County were found (cf. Fig. 6 for details).

\section{Discussion}

This paper makes two major contributions: firstly, we described a methodology for identifying key environmental factors associated with wildlife collisions where data are limited, and secondly, the analysis of our novel empirical data indicates that the situation in the Uckermark County is unexpectedly exceptional (compared with previously studied habitats) - highlighting the risk associated with extrapolating non-local data.

According to unpublished data of the Naturschutzstation Zippelsförde des Landesumweltamtes Brandenburg, road mortality is the most commonly recorded cause of death for otters in the Uckermark County, a fact that was also found in other regions of Germany (Körbel 2001; Sommer et al. 2005; Wölfel and Tessendorf 2000; Zinke 1991, 1998). In the Uckermark County, the volume of traffic has significantly increased between the years 1993 and 2000 (unpublished data of the Brandenburg Road Administration), while the number of otter casualties recorded has increased between 1990 and 2001 (unpublished data of the Naturschutzstation Zippelsförde des Landesumweltamtes Brandenburg). Similar results were found in Great Britain 
Table 3 Initial statistics from the discriminant analysisEigenvalues

${ }^{a}$ First two canonical discriminant functions were used in the analysis

\begin{tabular}{lcccc}
\hline Function & Eigenvalue & Percentage of variance & Cumulative (\%) & Canonical correlation \\
\hline 1 & $36.695^{\mathrm{a}}$ & 91.5 & 91.5 & 0.987 \\
2 & $3.406^{\mathrm{a}}$ & 8.5 & 100.0 & 0.879 \\
\hline
\end{tabular}

(Grogan et al. 2001; Philcox et al. 1999). One simple explanation for this correlation could be the increased risk of otter road kills due to increasing traffic volumes. However, in a study involving parallel roads with considerable differences in traffic volume, Clevenger et al. (2003) found lower numbers of mammal road kills in the road with higher traffic. For otters in Eastern Germany, this finding is supported by Hertweck et al. (1998) in an unpublished report from the Umweltforschungszentrum Leipzig (Raumnutzung und Migration des Fischotters Lutra lutra (L., 1758) in der Oberlausitzer Teichlandschaft. UZLAR Teilprojekt 3.1) who argue that on road sections with lower volumes of traffic, a higher frequency of road crossing otters should be expected. Another possible explanation for the rise of recorded road kills is an increase in the otter population during the time of investigation. A higher number of otters would in turn increase the number of otter casualties. Unfortunately, no population data for otters in the Uckermark County are available. Most otter casualties in the Uckermark County were recorded at road sections with a speed limit of $100 \mathrm{~km} /$ h (Fig. 4), which could be explained by a reduced reaction time of the driver.

Research in other regions shows that accident sites are typically located where a road crosses a watercourse as in group 3 of this study (Grogan et al. 2001; Körbel 2001; Philcox et al. 1999). In contrast to this, fewest accidents in the Uckermark County occur where a bridge or culvert was present at the accident site (Fig. 3). Furthermore, the relation between otter casualties per kilometre of bridges and culverts is only half of that of otter casualties per kilometre of road in the special topography of the Uckermark County. Besides representing low casualty numbers compared to other - albeit multi-species - studies on road mortality such as Grilo et al. (2009) or Malo et al. (2004), these results on the single species studied can be explained by the abundance of lakes in the Uckermark, whereas linear watercourses are less common than in other study areas. They also corroborate the results of other studies that find otters travelling overland for various purposes, e.g. to get from one body of water to the next (Green et al. 1984). Finally, every kind of water body in close proximity to a road creates a potential accident site since otters occur in a very wide range of aquatic habitats including both marine and freshwater systems (Kruuk 1995; Prauser and Röchert 1991).

The high number of otter casualties parallel to a water body leads to the conclusion that in landscapes abundant in lakes such as the Uckermark County, it is not sufficient to focus mitigation measures exclusively on bridges but also to create wildlife passages where a body of water occurs in close proximity to a road.

To identify potential accident sites, the investigation of a possible combination of features describing an accident site is essential. Therefore, the number of features describing an accident site had to be limited to significant characteristics by using a PCA.

The PCA yielded three groups of accident sites which were mainly characterised by the presence of a water body within a certain distance (group 1: lake within $200 \mathrm{~m}$; group 2: water body within a distance of more than $200 \mathrm{~m}$ ) and speed limit or, as in group 3, the presence of a culvert. These findings were then used to identify potential accident sites using GIS. This tool has successfully been used to create models of otter distribution (Janssens et al. 2006), for genetic and habitat caused distribution barriers (Hobbs et al. 2006), as well as to investigate distribution patterns of otters (Prigioni et al. 2006). In order to identify potential accident sites for group 1, road sections within $200 \mathrm{~m}$ of a lake were assessed with GIS and 226 sites were successfully identified (cf. Fig. 6 for details). Since speed limit is currently not available as GIS data for the Uckermark County, this variable could not been taken into account in the GIS analysis. This variable, however, should be included in future analyses of potential accident sites wherever this dataset is available. Nevertheless, since a strong correlation was found between speed limit (as assessed in the field) and number of otter road casualties in our study (Fig. 4), the potential accident sites within $200 \mathrm{~m}$ of a lake identified in the analysis were examined in the field. Out of these 226 identified potential accident sites, 138 were classified as especially dangerous since the speed limit at these locations was $100 \mathrm{~km} / \mathrm{h}$ or more.
Table 4 Initial statistics from the discriminant analysisWilks' Lambda

\begin{tabular}{lcccc}
\hline Test of function & Wilks' Lambda & Chi-square & df & Significance \\
\hline 1 through 2 & 0.006 & 408.991 & 22 & 0.000 \\
2 & 0.227 & 118.629 & 10 & 0.000 \\
\hline
\end{tabular}


Fig. 6 Example section of map with potential otter accident sites in the Uckermark County, Germany

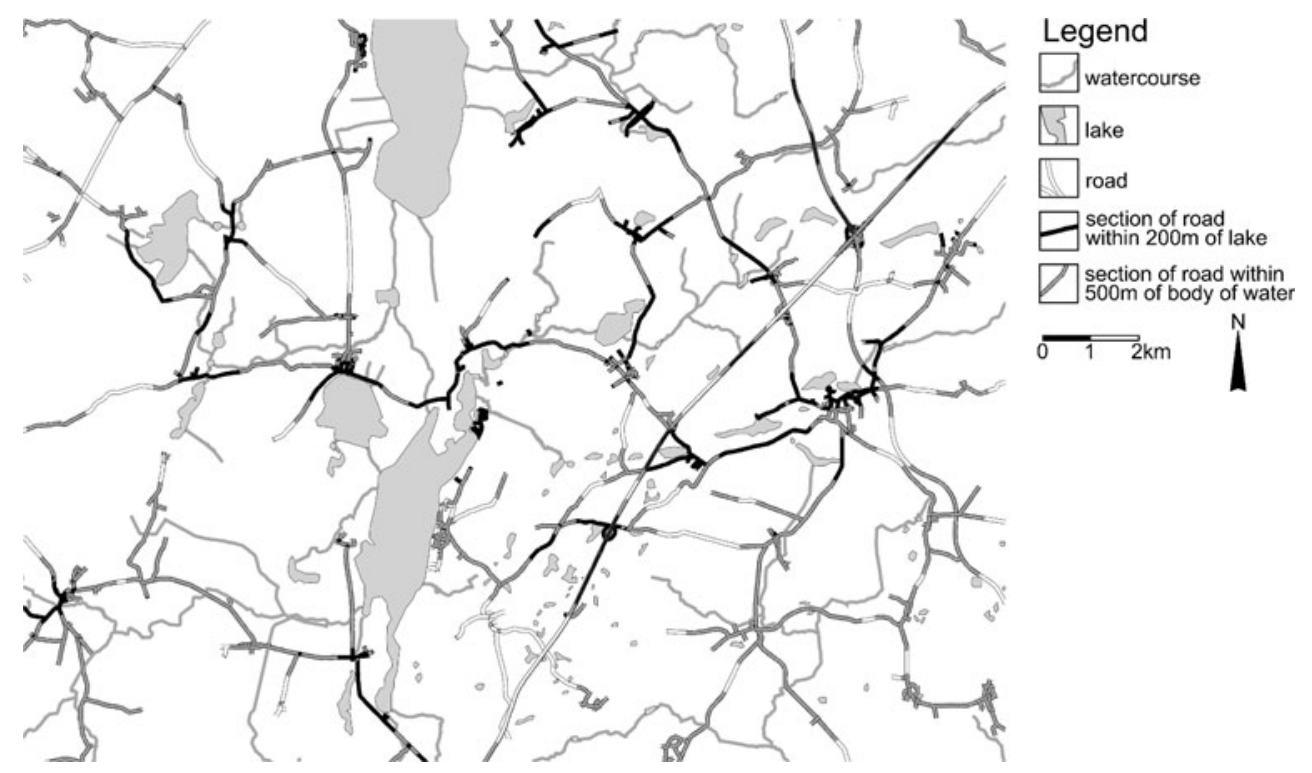

Particularly interesting is group 2, where no watercourse was present within a distance of $200 \mathrm{~m}$. This result is in stark contrast to what was expected at the outset of the study and to the situation encountered in other regions (Grogan et al. 2001; Körbel 2001; Philcox et al. 1999). A characteristic feature for this group was its location within a network of watercourses, which nevertheless is a characteristic feature for the entire Uckermark County. Therefore, it would be important to concentrate on finding important corridors used by otters between two utilised but distant habitats. This could be achieved through telemetry (cf. Zimmermann and Breitenmoser 2007; Drygala et al. 2008). Due to the strong correlation between distance and number of otter casualties (Fig. 2), ArcView GIS was also used to identify sites which lie within $500 \mathrm{~m}$ of water bodies. The 545 sites found that refer to group 2 represent a unique approach to assessing potential road hazards for otters, since otter road kills have so far predominantly been recorded close to river crossings, and distant accident sites have been neglected. However, the practical aspects of this result for mitigation measures will be limited to special cases due to the sheer number of identified potential accident sites.

In order to reduce otter road mortality, it is important to improve habitat connectivity. Because of the abundance of lakes in the Uckermark County, otters move across areas of dry land to get from one lake to another. Therefore, it is essential to provide passageways for wildlife such as underpasses or green bridges at the most important potential accident sites. The use of vegetation and fences to guide otters and other wildlife towards these tunnels and banks may improve the acceptance of these measures (Körbel 1995a, b, 2001). Tests on the Island of Skye, Scotland show that otter road mortality can also be significantly reduced by installing wildlife-deterring reflectors at dangerous sites (Yoxon 2006).
Since a speed limit of $100 \mathrm{~km} / \mathrm{h}$ was a significant feature at the accident sites, an otter traffic sign in conjunction with a lower speed limit can also be used to reduce otter deaths at problem sites, an option which is already being used in other regions (e.g. Mecklenburg-Western Pomerania, Northeast Germany). This method can be implemented instead of, or in conjunction with, the structural mitigation measures described above.

To improve the situation regarding group 3 , the conditions found at bridges and culverts must be considered. Different theories attempt to explain why some otters avoid swimming through culverts or under bridges. Reasons discussed are the increased water velocity under bridges, a "tunnel effect" or the lack of natural banks or even ledges (Madsen 1996; Grogan et al. 2001). If there is no natural bank, ledges on either side of the watercourse above the high water mark should be created for the use of otters and other wildlife as a mitigation measure. Since otters get killed at river crossings regardless of the existing speed limit, a reduction of the speed limit at these sites seems to have little influence on the improvement of the situation.

The mitigation measures described here may contribute to the reduction in the number of otter road casualties in the Uckermark County and elsewhere.

\section{Conclusions}

Our results show that most accidents happen where a road runs within $200 \mathrm{~m}$ of a lake. However, accidents in the Uckermark County also occur further away from water bodies. Because of the abundance of lakes, otters move longer distances over dry land between attractive habitat patches. Therefore, besides adequate bridges with ledges or natural banks, the construc- 
tion of wildlife underpasses is essential to reduce otter road mortality both in the study site and in general.

The GIS was shown to be an effective and useful tool for the prediction of potential accident sites for otters and could be similarly used for other wildlife species if the features of habitat fragmentation are known.

Acknowledgements We are indebted to Jens Teubner and staff members (Brandenburg State Office for Environment) and Katja Glante and Heidrun Kaiser as well as to the staff members of the Brandenburg Road Administration for providing data as well as logistic support. Hermann Ansorge (Staatliches Museum für Naturkunde Görlitz) is acknowledged for his advice and useful discussions of the topic. Henning Scholz (Museum für Naturkunde, Berlin), Christel Richter (Humboldt Universität zu Berlin) and Edith Braun (Freie Universität Berlin) provided valuable advice in our statistical analyses. We thank Siegfried Ostermaier (Forstamt Templin) and John Dye (Moy, Scotland) for supporting our GIS analyses, Lars Möller (Museum für Naturkunde, Berlin) for assistance with the data analysis, Eva Wochnik (Berlin) for her contribution to Fig. 1 and Ulrich Zeller (Humboldt Universität zu Berlin) for the formal supervision of the thesis of S. Jancke. Both Nicole Ulbrich (Galway, Ireland) and David Hetherington (Grantown-on-Spey, Scotland) are acknowledged for their linguistic advice. Two anonymous reviewers are acknowledged for useful suggestions and improvements of the manuscript.

\section{References}

Ansorge H (1994) Zur Situation des Eurasischen Fischotters Lutra lutra Linné, 1758 im Raum Oberlausitz-Sachsen. Säugetierkd Informationen 3:617-622

Binot M, Bless R, Boye P, Gruttke H, Pretscher P (1998) Rote Liste gefährdeter Tiere Deutschlands. Schriftenr Landschaftspflege Naturschutz 55:1-434

Clevenger AP, Chruszcz B, Gunson KE (2003) Spatial pattern and factors influencing small vertebrate fauna road-kill aggregations. Biol Cons 109:15-26

Convention on International Trade in Endangered Species (CITES) secretariat (1996) Convention on International Trade in Endangered Species of Wild Fauna and Flora. Available via http://www.cites.org/eng/app/e-appendices.pdf. Accessed 21 Feb 2010

Council of Europe (1996) Convention on the Conservation of European Wildlife and Natural Habitats-Recommendation No. 53 on the conservation of the European otter (Lutra lutra), adopted by the Standing Committee on 6 December 1996. Available via https://wcd.coe.int/com.instranet.InstraServlet?command=com. instranet.CmdBlobGet\&InstranetImage $=1325716 \&$ SecMode $=1 \&$ DocId $=1429412 \&$ Usage $=2$. Accessed $21 \mathrm{Feb} 2010$

de Jongh A (1999) De otter terug in Nederland! Zoogdier 10:27-32

Dolch D, Teubner J, Teubner J (1992) Der Fischotter im Land Brandenburg. Habitat 7:99-102

Dolch D, Teubner J, Teubner J (1998) Haupttodesursachen des Fischotters-Lutra lutra (L., 1758) im Land Brandenburg in der Zeit von 1990 bis 1994. Naturschutz und Landschaftspflege in Brandenburg 1:101

Drygala F, Stier N, Zoller H, Boegelsack K, Mix HM, Roth M (2008) Habitat use of the raccoon dog (Nyctereutes procyonides) in northeastern Germany. Mamm Biol 73:371-378

Field A (2009) Discovering statistics using SPSS. Sage Publications Ltd, London
Green R (1991) The impact of hunting, poaching and accidents on otter survival and measures to protect individual animals. Habitat 6:171-190

Green R, Green J (1997) Otter survey of Scotland 1991-1994. The Vincent Wildlife Trust, London

Green J, Green R, Jeffries DJ (1984) A radio-tracking survey of otters Lutra lutra on a Perthshire river system. Lutra 27:85-145

Grilo C, Bissonette JA, Santos Reis M (2009) Spatial-temporal patterns in Mediterranean carnivore road casualties: consequences for mitigation. Biol Cons 142:301-313

Grogan A, Philcox C, Macdonald D (2001) Nature conservation and roads: Advice in relation to otters. Report for the Highways Agency on the impact of roads and road construction on the otter in the United Kingdom. The Wildlife Conservation Research Unit, Oxford

Hauer S, Ansorge H, Zinke O (2002) Mortality patterns of otters (Lutra lutra) from Eastern Germany. J Zool London 256:361-368

Hertweck K, Frank K, Klenke R, Henle H (1998) Raumnutzung und Migration des Fischotters Lutra lutra (L., 1758) in der Oberlausitzer Teichlandschaft. UZLAR Teilprojekt 3.1 des Umweltforschungszentrums Leipzig-Halle

Hobbs GI, Chadwick EA, Slater FM, Bruford MW (2006) Landscape genetics applied to a recovering otter (Lutra lutra) population in the UK: preliminary results and potential methodologies. Hystrix 17:47-63

Janssens X, Defourny P, de Kerbmabon J, Baret P (2006) The recovery of the otter in the Cevennes (France): a GIS-based model. Hystrix 17:5-14

Körbel O (1995a) Hindering otter road kills. Part 1. IUCN Otter Spec Group Bull 11:14-20

Körbel O (1995b) Hindering otter road kills. Part 2. IUCN Otter Spec Group Bull 11:40-47

Körbel O (2001) Vermeidung der durch den Straßenverkehr bedingten Verluste von Fischottern (Lutra lutra). Forsch Straßenbau und Straßenverkehrstechnik 805:1-58

Kranz A, Vašek B, Buchli C, Toman A, Polednik L (2008) Zum Potential der natürlichen Wiederbesiedlung der Schweiz durch den Fischotter Lutra lutra. ALKA WILDLIFE Bericht 2008: 128. Available via http://prolutra.mibfinity.ch/images/stories/ $\mathrm{CH} \%$ 20Endbericht $\% 20$ Version\%2015102008-cb(1).pdf. Accessed 21 Sep 2009

Kruuk H (1995) Wild otter: predation and populations. Oxford University Press, Oxford

Macdonald S (1995) Otter distribution in Europe. Cah d'Ethologie 15:143-148

Madsen A (1996) Otter Lutra lutra mortality in relation to traffic, and experience with newly established fauna passages at existing road bridges. Lutra 39:76-90

Malo JE, Suárez F, Díez A (2004) Can we mitigate animal-vehicle accidents using predictive models? J Appl Ecol 41:701-710

Philcox CK, Grogan AL, Macdonald DW (1999) Patterns of otter Lutra lutra road mortality in Britain. J Appl Ecol 36:748762

Prauser N, Röchert R (1991) Habitat destruction and otters - suggestions towards a more systematic approach. Habitat 6:201-207

Prigioni C, Remonti L, Balestrieri A (2006) Otter Lutra lutra movements assessed by genotyped spraints in Southern Italy. Hystrix 17:91-96

Sommer R, Griesau A, Ansorge H, Priemer J (2005) Daten zur Populationsökologie des Fischotters Lutra lutra (Linnaeus, 1758) in Mecklenburg-Vorpommern. Beitr zur Jagd- \& Wildforschung 30:253-271

Strachan R, Jeffries DJ (1996) Otter survey of England 1991-94. The Vincent Wildlife Trust, London

Stubbe M (1977) Der Fischotter Lutra lutra in der DDR. Zool Anz Jena 199:265-285 
Stubbe M (1978) Der Fischotter Lutra lutra (L., 1758) in den mittleren Bezirken der DDR. Hercynia 15:77-105

Stubbe M, Heidecke D, Stubbe A (1993) Tiere im Konflikt 1, Monitoring Fischotter 1985-1991. Martin Luther Universität Halle-Wittenberg, Halle (Saale)

Teubner J, Teubner J, Dolch D, Blum H (1999) Die aktuelle Verbreitung des Fischotters Lutra lutra (L., 1758) im Land Brandenburg. Naturschutz und Landschaftspflege in Brandenburg 8:82-92

Uthleb H, Stubbe M, Heidecke D, Ansorge H (1992) Zur Populationsstruktur des Fischotters Lutra lutra (L. 1758) im östlichen Deutschland. Semiaquatische Säugetiere 1992:393400

Weber D, Weber JM, Müller HU (1991) Fischotter (Lutra lutra) im Schwarzwasser-Sense-Gebiet: Dokumentation eines gescheiterten Wiedereinbürgerungsversuchs. Mitt Naturforsch Ges Bern $48: 141-152$
Wölfel L, Tessendorf F (2000) Ein kohärentes Netz von Schutzgebieten für den Fischotter in Mecklenburg-Vorpommern. Schriftenr Landschaftspflege Naturschutz 68:91-99

Yoxon P (2006) Alleviating otter (Lutra lutra) road deaths by using wildlife-warning reflectors, on the Isle of Skye. International Otter Survival Fund, Broadford

Zimmermann F, Breitenmoser U (2007) Potential distribution and population size of the Eurasian lynx (Lynx lynx) in the Jura Mountains and possible corridors to adjacent ranges. Wildl Biol 13:406-416

Zinke O (1991) Die Todesursachen der im Museum der Westlausitz Kamenz von 1985-1991 eingelieferten Fischotter Lutra lutra (L., 1758). Veröff d Museums d Westlausitz 15:57-63

Zinke O (1998) Fischotterverluste in der Westlausitz und angrenzenden Gebieten in den Jahren 1985 bis 1995. Naturschutz und Landschaftspflege in Brandenburg 1:103-104 